\title{
PROPOZYCJA POPRAWY STANU ENERGETYCZNEGO \\ W OSIEDLU MIESZKANIOWYM NA PODSTAWIE \\ OCENY DOTYCHCZASOWYCH TERMOMODERNIZACJI WIELORODZINNYCH BUDYNKÓW PREFABRYKOWANYCH
}

\author{
Anna Ostańska ${ }^{1}$, Katarzyna Taracha ${ }^{2}$ \\ ${ }^{1}$ Politechnika Lubelska, Wydział Budownictwa i Architektury, Katedra \\ Architektury, Urbanistyki i Planowania Przestrzennego \\ e-mail: a.ostanska@pollub.pl
}

Streszczenie. W opracowaniu podjęto próbę oceny dotychczasowych modernizacji na przykładzie typowych wielorodzinnych budynków prefabrykowanych zrealizowanych w systemie W-70. Zaproponowano też możliwe działania, które mogą mieć wpływ na obniżenie zużycia energii w budynkach i osiedlu.

Słowa kluczowe: termomodernizacja, energooszczędność, rewitalizacja

\section{WSTĘP}

Nad potrzebą termomodernizacji w Polsce chyba już nikt nie dyskutuje, ponieważ rosnące ceny nośników energii poniekąd zmuszają właścicieli i zarządców nieruchomości do wejścia na ścieżkę oszczędzania, która powinna być efektem inwestowania. Pytanie czy zmieniło się na jak inwestować i w którym kierunku pójść? Bowiem coraz częściej rozważa się poprawę stanu energetycznego nie tylko w skali budynków, ale i osiedli mieszkaniowych.

\section{DANE OGÓLNE}

Na podstawie literatury [Dzierżewicz 2010] stwierdzono, że system W-70 był realizowany głównie w regionie południowo-wschodnim Polski, w województwach: lubelskim, radomskim, kieleckimi krakowskim oraz $\mathrm{w}$ innych regionach kraju (Ryc. 1).

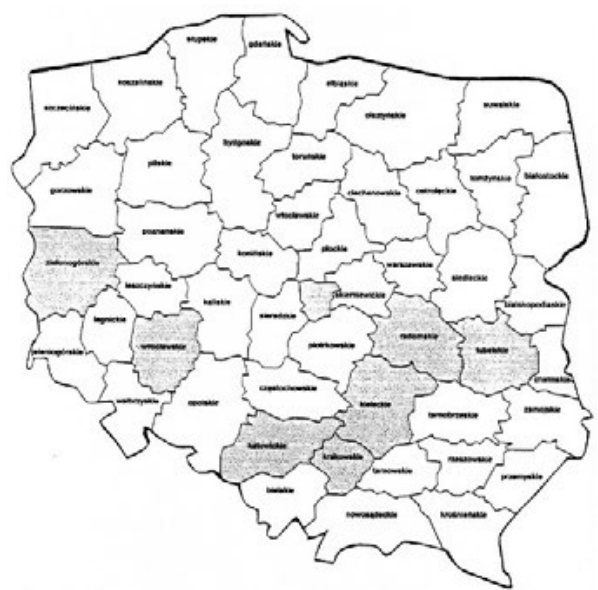

Ryc. 1. Lokalizacja budownictwa W-70 [Dzierżewicz 2010]

Fig. 1. Distribution of W-70 precast concrete panel system buildings 
Autorka przedstawiła już w serii artykułów [1, 2, 3, 4, 5] i monografii [Ostańska 2009] problemy związane $\mathrm{z}$ rewitalizacją wielkiej płyty w podejściu wieloaspektowym. Wymaga to jednak podjęcia wymiernych działań, aby móc skutecznie skorzystać $\mathrm{z}$ zaproponowanych autorskich rozwiązań. Jednym z poruszanych aspektów, zaliczonych do trzech podstawowych w badaniach diagnostycznych, jest stan energetyczny budynków w skali osiedla. Związany jest on ściśle z przeprowadzanymi działaniami termomodernizacyjnymi, m.in. na budynkach mieszkalnych.

W celu oceny dotychczasowych realizacji i dalszych potrzeb działań naprawczych, autorka przeprowadziła badania własne na terenie lubelskiego osiedla im. Karola Szymanowskiego będącego w zarządzie SM Czechów.

Osiedle powstało na początku lat osiemdziesiątych XX wieku, a na początku lat dziewięćdziesiątych, ze względu na błąd projektowy w analizowanym systemie, budynki mieszkalne były ocieplane metodą: lekka sucha za pomocą wełny lub styropianu zabezpieczonych okładziną z płyt ligno-cementowych lub lekka mokra na styropianie zabezpieczonego odpowiednią wyprawą tynkarską. Na niektórych budynkach stan taki pozostał do dziś (co szczegółowo opisano w p. 2). Pod koniec lat dziewięćdziesiątych ocieplono też stropodachy granulatem $\mathrm{z}$ wełny mineralnej. Pomimo, że zarządca wykonał ostatnio audyty energetyczne, to większość z budynków czeka na możliwość sfinansowania realizacji. Wydaje się więc, że jest to dobry czas, aby móc szerzej rozważyć opcje termomodernizacji niż wynika to z zaleceń standardowych audytów, które dają przeważnie nie więcej niż 30\% możliwych oszczędności przy czym należy podkreślić, iż są one zgodne z obowiązującymi przepisami.

\section{STAN BUDYNKÓW WIELKOPŁYTOWYCH}

Poniżej poddano analizie pięć wybranych reprezentatywnych typów budynków wielkopłytowych znajdujących się na osiedlu im. Karola Szymanowskiego w Lublinie. Wyróżniono następujące budynki: niskie do 5. kondygnacji, średniowysokie od 7 do 9 kondygnacji i wysokie od 11 kondygnacji; klatkowe - segmentowe i punktowe $-\mathrm{z}$ galerią wewnętrzną lub korytarzowe. Wszystkie obiekty są przynajmniej po I etapie ocieplenia (p.1), choć w ostatnich latach wykonano też $\mathrm{w}$ nich inne prace, takie jak wymiana oświetlenia przed klatkami i w prześwitach na LED. Wybrane do analizy budynki są obecnie w stanie:

oczekiwania na planowaną termomodernizację,

realizacji działań termomodernizacyjnych,

po realizacji termomodernizacji II etapu.

Wszystkie działania termomodernizacyjne zaplanowano na podstawie audytów energetycznych wykonanych, przez osobę uprawnioną, zgodnie z obowiązującymi rzepisami.

W ramach oceny technicznej dotychczasowych działań wykonano wizje lokalne, dokumentację fotograficzną i badania in situ oraz bezinwazyjne badania termograficzne budynków. $\mathrm{Na}$ tej podstawie poddano analizie stan techniczny wybranych elementów elewacji, z uwzględnieniem stanu energetycznego. Dla większości osiedlowych budynków (w tym 3 analizowane) zaplanowano $\mathrm{w}$ najbliższym czasie ponowne prace termomodernizacyjne, w których przewidziano usunięcie będącego w złym stanie ocieplenia I etapu, a następnie wykonanie docieplenia ścian metodą Bezspoinowego Systemu Ocieplenia (system na styropianie). Poniżej przedstawiono ocenę stanu dotychczasowych termomodernizacji na wyróżnionych typach budynków prefabrykowanych i przedstawiono wybrane termogramy, które obrazują niezlikwidowane jeszcze problemy przemarzania ścian mimo przeprowadzenia, przynajmniej jednego etapu termicznej modernizacji. 


\section{BUDYNEK KLATKOWY NISKI PRZED PLANOWANĄ TERMOMODERNIZACJĄ}

Reprezentantem tego typu obiektów jest budynek znajdujący się przy ul. Harnasie 3.

Budynek o pięciu kondygnacjach nadziemnych, podpiwniczony, zabudowa szeregowa (2 segmenty, ryc. 2), dwuklatkowy, technologia uprzemysłowiona, system wielkopłytowy W-70. Rok budowy 1980. Układ konstrukcyjny poprzeczny. Ławy żelbetowe monolityczne. Ściany systemu W-70, konstrukcyjne: żelbetowe zewnętrzne warstwowe żelbet+styropian+beton, osłonowe prefabrykowane, całość ocieplona styropianem, zabezpieczonym płytami ligno-cementowymi - wykonano w latach 90. Stropy prefabrykowane kanałowe. Stropodach na płytach korytkowych, wentylowany na ściankach ażurowych, kryty papą termozgrzewalną, ocieplony płytą suprema i granulatem z wełny mineralnej. Stolarka okienna w mieszkaniach drewniana zespolona podwójnie szklona lub wymieniona na PCV, niekiedy drewniana jednoramowa z szybą zespoloną jednokomorową. Stolarka okienna na klatkach schodowych i w piwnicach PCV (ryc.3). Drzwi wejściowe aluminiowe, energooszczędne. Wentylacja grawitacyjna w kuchniach i łazienkach. C.o. i c.w. zdalaczynne z sieci miejskiej LPEC, zasilanie $\mathrm{z}$ grupowego dwufunkcyjnego węzła wymiennikowego w piwnicach budynku, wyposażona w automatykę pogodową. Piwnice nieogrzewane.

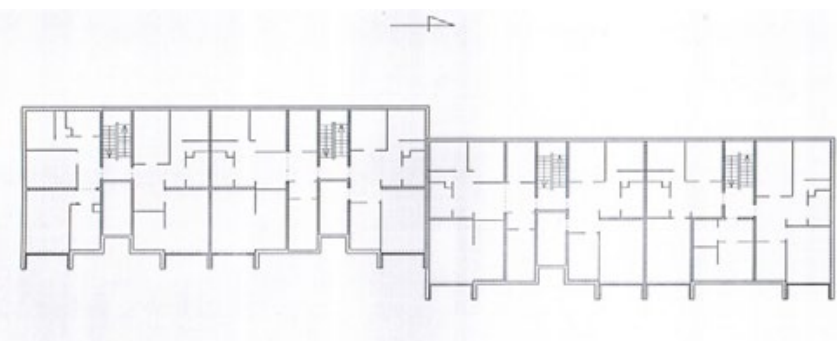

Ryc. 2. Dokumentacja archiwalna - w posiadaniu zarządcy

Fig. 2. Archives stored by facility manager

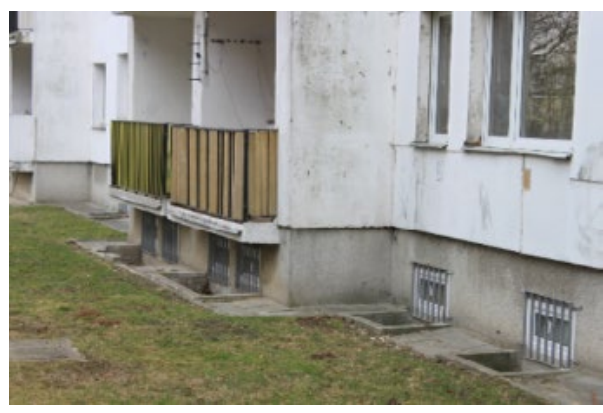

Ryc. 3. Harnasie 3. Fragment budynku prefabrykowanego z 1980 r. po ociepleniu w latach 90. i częściowej wymianie stolarki okiennej

Fig. 3. Precast panel block of flats of nineteeneighties - insulated in nineteen-nineties, with windows partially replaced

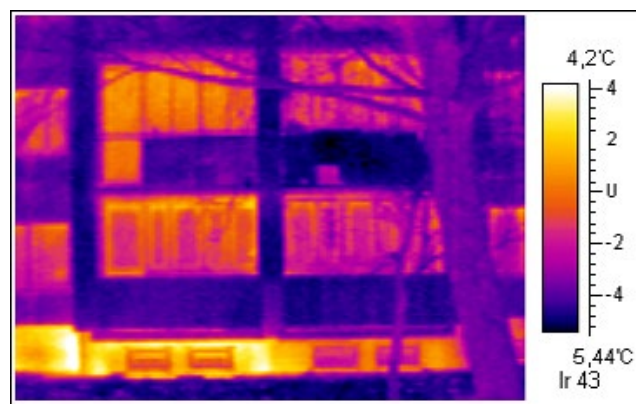

Ryc. 4. Termogram do ryc. 3. Ucieczka ciepła przez cokół, zróżnicowana stolarka okienna, $\mathrm{E}_{\mathrm{k}}=198,17 \mathrm{kWh} /\left[\mathrm{m}^{2} \cdot\right.$ rok $]$

Fig. 4. Thermal image of the same building: uninsulated basement wall, non-uniform thermal properties of windows, $\mathrm{E}_{\mathrm{k}}=198,17 \mathrm{kWh} /\left[\mathrm{m}^{2} \cdot\right.$ year $]$

Mimo ocieplenia ścian w I etapie (Ryc. 3) zauważono ucieczkę ciepła przez cokół, z nasileniem na styku płyt prefabrykowanych (Ryc. 4). Ogólny stan techniczny budynku oceniono jako dostateczny. 


\section{BUDYNEK PUNKTOWY NISKI PRZED PLANOWANĄ TERMOMODERNIZACJĄ}

Reprezentantem tego typu obiektów jest budynek znajdujący się przy ul. Noskowskiego 8 .

Budynek o pięciu kondygnacjach nadziemnych (Ryc.6), podpiwniczony, zabudowa punktowa (dwa segmenty stykające się ze sobą, (Ryc.5), punktowy z galeriami wewnętrznymi, technologia uprzemysłowiona, system wielkopłytowy W-70. Rok budowy 1980. Układ konstrukcyjny mieszany. Ławy żelbetowe monolityczne. Ściany konstrukcyjne żelbetowe, zewnętrzne warstwowe żelbet+styropian+beton, ściany osłonowe prefabrykowane, ocieplone, styropianem zabezpieczonym wyprawą tynkarską - wykonane w latach 90. Stropy prefabrykowane kanałowe. Stropodach na płytach korytkowych, wentylowany na ściankach ażurowych, kryty papą termozgrzewalną, ocieplony płytą suprema i granulatem z wełny mineralnej. Stolarka okienna w mieszkaniach drewniana zespolona podwójnie szklona lub wymieniona na $\mathrm{PCV}$, niekiedy drewniana jednoramowa z szybą zespoloną jednokomorową. Stolarka okienna na klatkach schodowych PCV i drewniana (piwnice). Drzwi wejściowe stalowe, nieocieplone. Wentylacja grawitacyjna w kuchniach i łazienkach. Centralne ogrzewanie i ciepła woda zdalaczynne z sieci miejskiej LPEC, zasilanie z grupowego dwufunkcyjnego węzła wymiennikowego w piwnicach budynku, wyposażona w automatykę pogodową. Piwnice nieogrzewane.

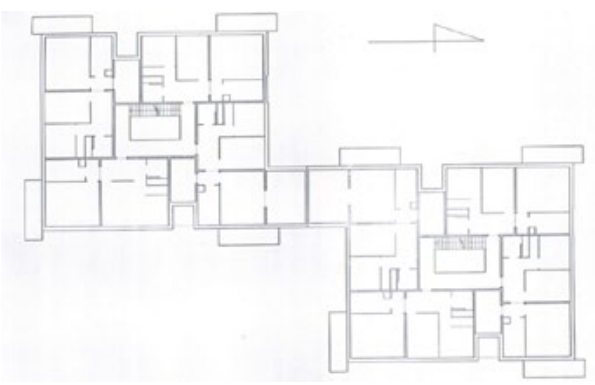

Ryc. 5. Dokumentacja archiwalna - w posiadaniu zarządcy

Fig. 5. Archives stored by facility manager

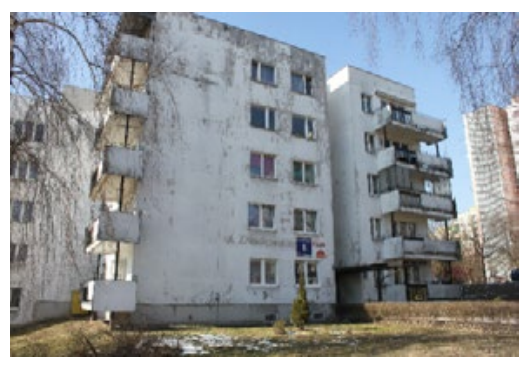

Ryc. 6. Noskowskiego 8. Budynek prefabrykowany z 1980 r. po ociepleniu w latach 90. i częściowej wymianie stolarki okiennej

Fig. 6. A block at Noskowskiego 8. The building of nineteen-eighties - insulated in nineteennineties,, with windows partially replaced

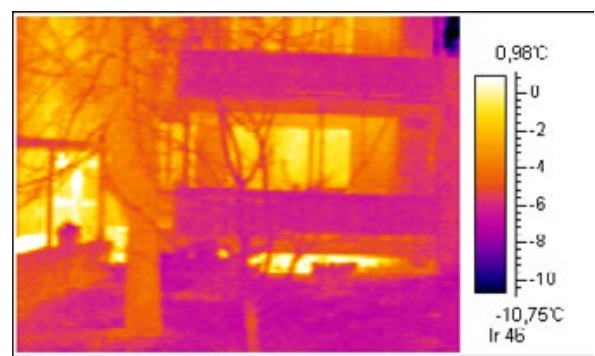

Ryc. 7. Termogram do ryc. 6. Ucieczka ciepła przez ściany, z nasileniem w strefie cokołu i wejścia, $E_{k}=231,71 \mathrm{kWh} /\left[\mathrm{m}^{2} \cdot\right.$ rok $]$

Fig. 7. Thermal image of the same building: heat losses in the basement and at the entrance, $E_{k}=231.71 \mathrm{kWh} /\left[\mathrm{m}^{2} \cdot\right.$ year $]$

Zauważono ucieczkę ciepła całą powierzchnią ścian z nasileniem: w strefie cokołu (mimo nieogrzewanych piwnic), dodatkowo przez stolarkę zewnętrzną, szczególnie drzwi wejściowe i płyty loggi (Ryc. 7). Ogólny stan techniczny budynku oceniono jako dostateczny. 


\section{BUDYNEK KLATKOWY WYSOKI PRZED PLANOWANĄ TERMOMODERNIZACJĄ}

Reprezentantem tego typu obiektów jest budynek znajdujący się przy ul. Harnasie 19.

Budynek o pięciu- i siedmiukondygnacjach (Ryc. 9), podpiwniczony, zabudowa szeregowa (3 segmenty), dwuklatkowy (Ryc. 8), technologia uprzemysłowiona, system wielkopłytowy W-70. Rok budowy 1983. Układ konstrukcyjny poprzeczny. Lawy żelbetowe monolityczne. Ściany systemu W-70, konstrukcyjne żelbetowe, zewnętrzne warstwowe żelbet+styropian+beton, ściany osłonowe prefabrykowane, całość ocieplona - styropian zabezpieczonym płytami ligno-cementowymi - wykonano w latach 90. (Ryc. 11) Stropy prefabrykowane kanałowe. Stropodach na płytach korytkowych, wentylowany na ściankach ażurowych, kryty papą termozgrzewalną, ocieplony płytą suprema i granulatem z wełny mineralnej. Stolarka okienna w mieszkaniach drewniana zespolona podwójnie szklona lub wymieniona na $\mathrm{PCV}$, niekiedy drewniana jednoramowa z szybą zespoloną jednokomorową. Stolarka okienna na klatkach schodowych drewniana zespolona podwójnie szklona. Drzwi wejściowe aluminiowe, energooszczędne (Ryc. 10). Wentylacja grawitacyjna w kuchniach i łazienkach. Cenralne ogrzewanie i ciepła woda zdalaczynne z sieci miejskiej LPEC, zasilanie z grupowego dwufunkcyjnego węzła wymiennikowego w piwnicach budynku, wyposażona w automatykę pogodową. Piwnice nieogrzewane.

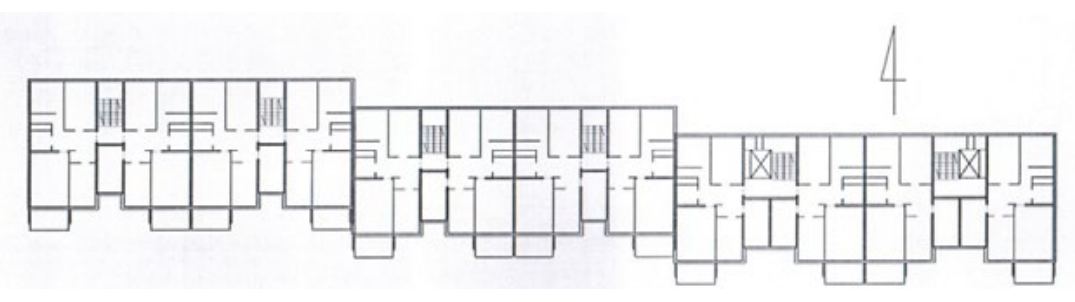

Ryc. 8. Dokumentacja archiwalna - w posiadaniu zarządcy

Fig. 8. Archives stored by facility manager

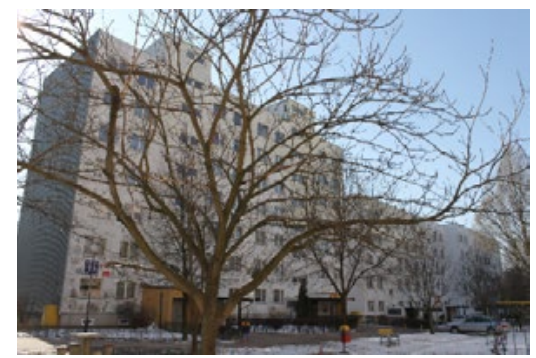

Ryc. 9. Harnasie 19. Budynek prefabrykowany z 1983 r. po ociepleniu w latach 90. i częściowej wymianie stolarki okiennej Fig. 9. Building at Harnasie 19, erected in 1983, - insulated in nineteen-nineties, with windows partially replaced

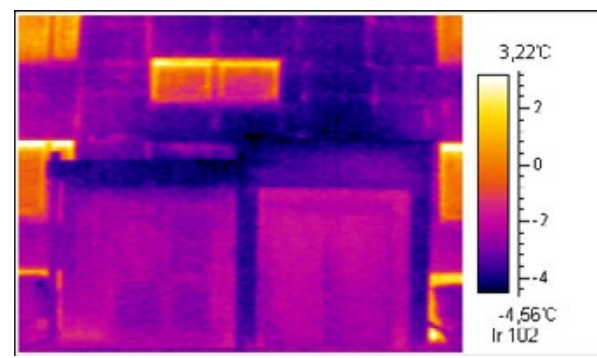

Ryc. 10. Termogram do ryc. 9. Stolarka drzwiowa zewnętrzna wymieniona. Brak intensywnej ucieczki ciepła w strefie wejściowej. $226,16 \mathrm{kWh} /\left[\mathrm{m}^{2} \cdot \mathrm{rok}\right]$

Fig. 10. Thermal image of the same building: replaced door reduced energy losses, $226.16 \mathrm{kWh} /\left[\mathrm{m}^{2} \cdot\right.$ year $]$ 


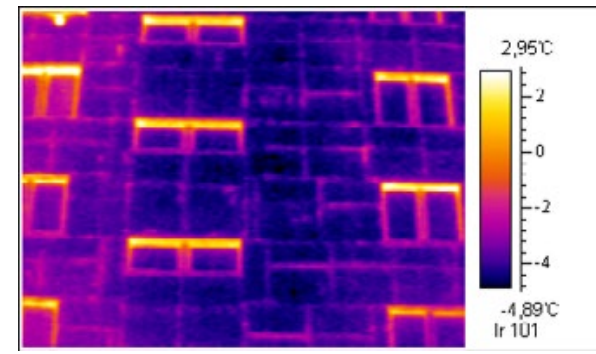

Ryc. 11. Termogram do ryc. 9. Ucieczka ciepła przez ściany, z nasileniem w strefie cokołu i wejścia. Fig. 11. Thermal image of the same building: thermal bridges in the facade, heat losses increased at the basement and at the entrance

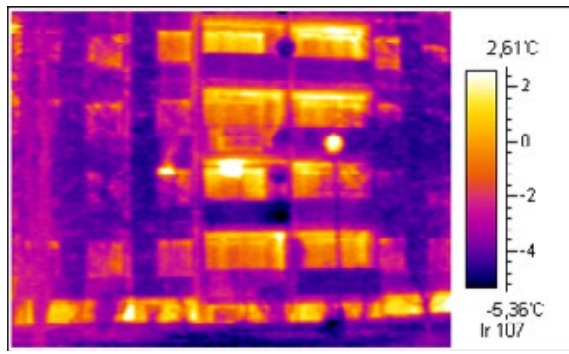

Ryc. 12. Termogram do ryc. 8. Ucieczka ciepła przez cokół i styki połączeń płyt balkonowych w loggi dostawianej

Fig. 12. Thermal image of the same building: heat losses in the basement and balcony slabs

Zauważono ucieczkę ciepła całą powierzchnią ścian z nasileniem na stykach płyt osłonowych (Ryc. 11) i przez cokół, mimo nieogrzewanych piwnic. Ciepło ucieka też przez stolarkę okienną i lokalnie styk płyt loggi ze ścianą osłonową (Ryc. 12). Ogólny stan techniczny budynku oceniono jako dostateczny.

\section{BUDYNEK KLATKOWY WYSOKI W TRAKCIE TERMOMODERNIZACJI}

Reprezentantem tego typu obiektów jest budynek narożny znajdujący się u zbiegu ulic Harnasie 21/Zakopiańska 1 (Ryc. 14).

Budynek o siedmiu-., dziewięciu- i jedenastukondygnacjach nadziemnych, podpiwniczony, zabudowa szeregowa (7 segmentów, Ryc. 13), dwuklatkowy, technologia uprzemysłowiona, system wielkopłytowy W-70. Rok budowy 1983. Układ konstrukcyjny poprzeczny. Ławy żelbetowe monolityczne. Ściany konstrukcyjne żelbetowe, zewnętrzne warstwowe żelbet+styropian+beton, ściany osłonowe prefabrykowane całość + styropian zabezpieczony płytami ligno-cementowymi. Stropy prefabrykowane kanałowe. Elewacje w trekcie ocieplania (metoda BSO). Stropodach na płytach korytkowych, wentylowany na ściankach ażurowych, kryty papą termozgrzewalną, ocieplony płytą suprema i granulatem z wełny mineralnej. Stolarka okienna w mieszkaniach drewniana zespolona podwójnie szklona lub wymieniona na PCV lub drewniane jednoramowe z szybą zespoloną jednokomorową. Stolarka okienna na klatkach schodowych drewniana zespolona podwójnie szklona. Drzwi wejściowe aluminiowe, szklone, energooszczędne. Wentylacja grawitacyjna w kuchniach i łazienkach. Centralne ogrzewanie i ciepła woda zdalaczynne z sieci miejskiej LPEC, zasilanie z grupowego dwufunkcyjnego węzła wymiennikowego w piwnicach budynku, wyposażona $\mathrm{w}$ automatykę pogodową. Piwnice nieogrzewane. 


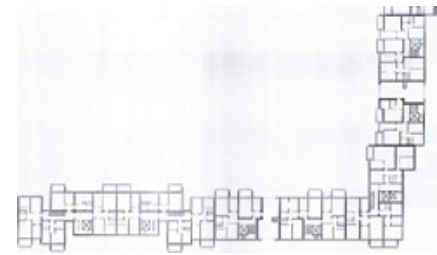

Ryc. 13. Dokumentacja archiwalna - w posiadaniu zarządcy

Fig. 13. Archives stored by facility manager

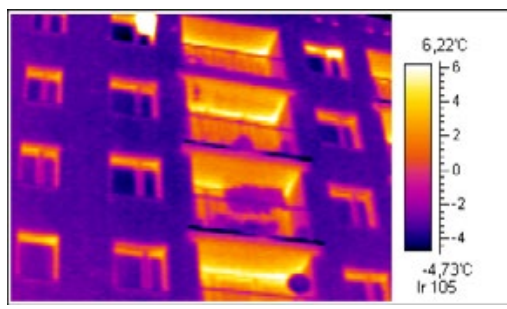

Ryc. 15. Termogram do ryc. 13. Zwiększona ucieczka ciepła na styku logii cofniętej ze

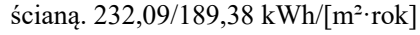

Fig. 15. Thermal image of the same building: Heat losses in loggias, $232.09 \mathrm{kWh} /\left[\mathrm{m}^{2} \cdot\right.$ year $]$

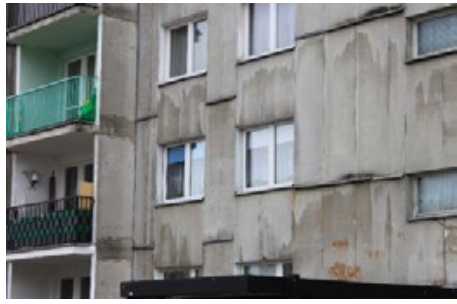

Ryc. 17. Fragment budynku prefabrykowanego po I etapie ocieplenia. Zły stan płyt okładzinowych

Fig. 17. Poor condition of cladding of the first stage of thermal insulation

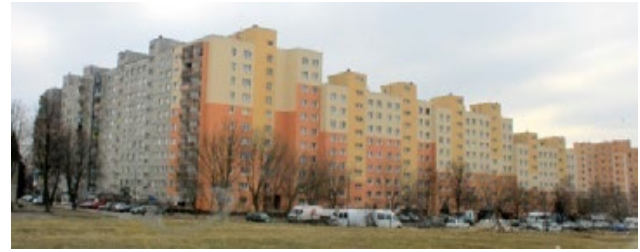

Ryc. 14. Harnasie 21/Zakopiańska 1. Budynek prefabrykowany z 1986 r. po ociepleniu w latach 90. i częściowej wymianie stolarki okiennej. Widok ogólny od strony północno-wschodniej Fig. 14. Building at the corner of Harnasie 21 and Zakopiańska 1, erected in 1986,

insulated in nineteen-nineties, with windows partially replaced - south-east view

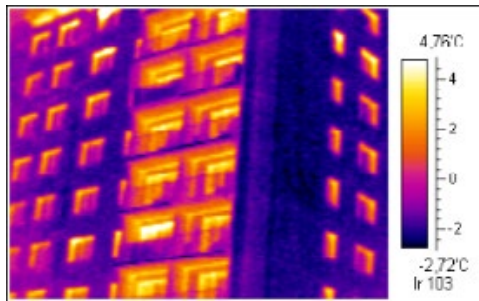

Ryc. 16. Termogram do ryc. 14. Narożnik północnowschodni. Mostki przy płytach loggi dostawianych

Fig. 15. Thermal image of the same building: Heat losses in loggias

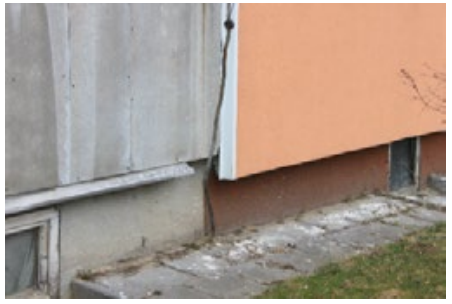

Ryc. 18. Fragment budynku prefabrykowanego na styku I i II etapu ocieplenia. Zły stan płyt okładzinowych i stolarki okiennej, brak ocieplenia cokołu w obu etapach ocieplenia

Fig. 18. Second stage of insulation and old cladding of the first stage. Poor condition of old cladding and basement joinery, uninsulated basement wall.

W segmentach ocieplonych w I etapie zauważono ucieczkę ciepła całą powierzchnią ścian z nasileniem na stykach płyt osłonowych. Ciepło ucieka też dodatkowo przez stolarkę okienną i styki płyt loggi ze ścianą osłonową (Ryc. 17). Natomiast w segmentach będących po II etapie ocieplenia, co prawda stwierdzono zmniejszenie ucieczki ciepła przez ściany, ale również nasilenie jej ucieczki na stykach płyt balkonowych ze ścianą osłonową. Świadczy to o nieskutecznej naprawie mostka termicznego i pozostawieniu problemu zarówno przy płytach w loggiach dostawianych (Ryc. 16), jak i cofniętych (Ryc. 15). Brak ocieplania na 
cokołach (Ryc. 18) pozwala na ucieczkę ciepła przez ten element. Ogólny stan techniczny budynku oceniono jako dostateczny (w segmentach ocieplonych tylko w I etapie) i zadowalający (w segmentach po II etapie ocieplenia).

\section{BUDYNEK PUNKTOWY WYSOKI PO TERMOMODERNIZACJI}

Reprezentantem tego typu obiektów jest budynek znajdujący się przy ul. Króla Rogera 6 (Ryc. 20).

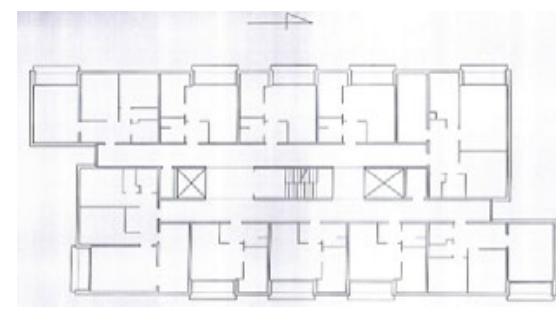

Ryc. 19. Króla Rogera 6. Dokumentacja archiwalna - w posiadaniu zarządcy Fig. 19. Building at Krola Rogera 6. Archives stored by facility manager

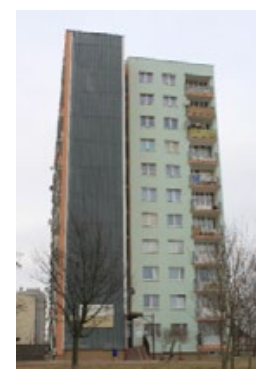

Ryc. 20. Króla Rogera 6. Budynek prefabrykowany z 1986 r. po ociepleniu w latach 90. i częściowej wymianie stolarki okiennej. Widok ogólny od strony północno-wschodniej Widok ogólny od strony południowej

Fig. 20. Building at Krola Rogera 6, erected in 1986. Insulated in nineteen-nineties, with windows partially replaced. South-east view.

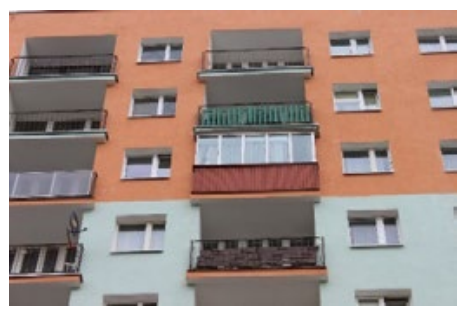

Ryc. 21. Fragment elewacji zachodniej po II etapie ocieplenia. Widok zabudowy loggi cofniętej, patrz termogram ryc. 22

Fig. 21. West elevation after second stage of thermal insulation - recessed loggias

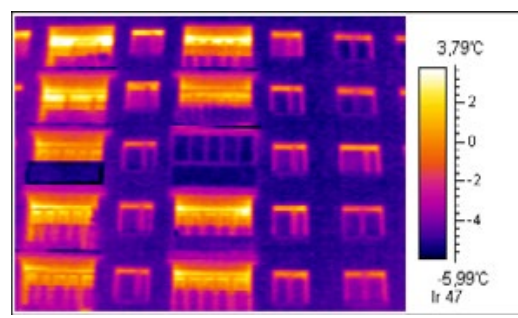

Ryc. 22. Termogram do ryc. 20.

Ucieczka ciepła liniowo przy balkonach $197,18 / 167,01 \mathrm{kWh} /\left[\mathrm{m}^{2} \cdot\right.$ rok $]$.

Fig. 22. Thermal image of the same building: Heat losses at balconies

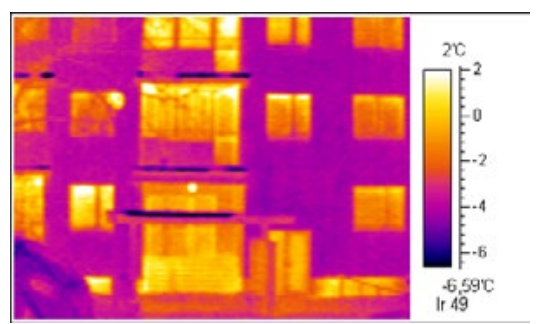

Ryc. 23. Termogram do rys. 20. Ucieczka ciepła przez cokół i stolarkę drzwiową zewnętrzną. Fig. 22. Thermal image of the same building: Heat losses at basement walls and windows 
Budynek o jedenastu kondygnacjach nadziemnych, podpiwniczony, zabudowa wolno stojąca, punktowy z dwoma korytarzami, technologia uprzemysłowiona, system wielkopłytowy W-70. Rok budowy 1981. Układ konstrukcyjny mieszany. Ławy żelbetowe monolityczne. Ściany konstrukcyjne W-70, konstrukcyjne: żelbetowe zewnętrzne warstwowe żelbet+styropian+beton, ściany osłonowe prefabrykowane. Stropy prefabrykowane W-70 kanałowe. Stropodach jednospadowy wentylowany, kryty papą termozgrzewalną, ocieplony płytą suprema i granulatem z wełny mineralnej. Stolarka okienna w mieszkaniach drewniana zespolona podwójnie szklona, cześciowo wymienione na PCV lub drewniana jednoramowa z szybą zespoloną jednokomorową. Stolarka okienna na klatkach schodowych drewniana zespolona podwójnie szklona. Drzwi wejściowe stalowe, szklone szybą zbrojoną - zimne. Wentylacja grawitacyjna w kuchniach i łazienkach. Centralne ogrzewanie i ciepła woda zdalaczynne z sieci miejskiej LPEC, zasilanie z grupowego dwufunkcyjnego węzła wymiennikowego w budynku, wyposażona $\mathrm{w}$ automatykę pogodową. Piwnice nieogrzewane.

Stwierdzono zmniejszenie ucieczki ciepła przez ściany z równoczesnym nasileniem ucieczki ciepła na stykach płyt balkonowych ze ścianą zewnętrzną (Ryc. 22). Sytuacja ta nie dotyczy płyty loggi zabudowanej (Ryc. 21). Świadczy to o nieskutecznej naprawie liniowego mostka termicznego i pozostawieniu problemu przy płytach w loggiach cofniętych. Ponadto stolarka drzwiowa zewnętrzna stanowi słaby punkt pod względem termicznym w całości ocieplenia II etapu, ponieważ nie jest energooszczędna (Ryc. 23). Ogólny stan techniczny budynku oceniono jako zadowalający.

\section{PROPOZYCJE POPRAWY STANU ENERGETYCZNEGO W OSIEDLU MIESZKANIOWYM}

W tab. 1 zestawiono wymagania zapotrzebowania na energię budynków według obowiązujących przepisów.

Tabela 1. Wymagania stawiane budynkom wg kryterium wieku lub planowanego stanu energetycznego

Table 1. Historic building code requirements and requirements for the increased thermal standard

\begin{tabular}{|c|c|c|}
\hline $\begin{array}{l}\text { Budynek } \\
\text { Building }\end{array}$ & $\begin{array}{l}\text { Wskaźnik sezonowego zapotrzebowa- } \\
\text { nia na energię } \\
\text { Seasonal energy demand } \\
\mathrm{E}_{0}\left[\mathrm{kWh} / \mathrm{m}^{2} \text { rok }\right]\end{array}$ & $\begin{array}{l}\text { Zapotrzebowanie na energię } \\
\text { w stosunku do standardu } \\
\text { Relative to current building code } \\
\text { standard building } \\
\text { [\%] }\end{array}$ \\
\hline $\begin{array}{l}\text { Inwentaryzowany, wykonany } \\
\text { w latach 1967-1985 } \\
\text { As originally built between } 1967 \\
\text { and } 1985\end{array}$ & $240-290$ & 265 \\
\hline $\begin{array}{l}\text { Inwentaryzowany, wykonany } \\
\text { w latach 1986-1992 } \\
\text { As originally built between } 1986 \\
\text { and } 1992\end{array}$ & $160-200$ & 180 \\
\hline $\begin{array}{l}\text { Standardowy } \\
\text { Current building code standard }\end{array}$ & $90-120$ & 100 \\
\hline $\begin{array}{l}\text { Energooszczędny } \\
\text { Energy efficient }\end{array}$ & $50-80$ & 70 \\
\hline $\begin{array}{l}\text { Zeroenergetyczny } \\
\text { Zero-energy building }\end{array}$ & $\begin{array}{l}\text { Blisko } 0 \\
\text { Nearly } 0\end{array}$ & $\begin{array}{l}\text { W zasadzie samowystarczalność } \\
\text { energetyczna } \\
\text { Practically energy autarkic }\end{array}$ \\
\hline
\end{tabular}


W analizowanej reprezentatywnej grupie budynków w systemie wielkopłytowym dotychczasowe działania termomodernizacyjne powstrzymały degradację obiektów i zmniejszyły zapotrzebowanie na energię (Tab. 1). Jednocześnie zauważono możliwość poprawy stanu energetycznego osiedla poprzez likwidację błędów zestawionych w poszczególnych obiektach pozostawione nawet po kilku etapach docieplenia. W pierwszej kolejności należy poddać naprawie wyspecyfikowane miejsca problemowe, takie jak: cokoły, styk płyt balkonowych wszystkich rodzajów (loggi cofniętych i dostawianych), należy też zwrócić uwagę przy wymianie stolarki okiennej na parametry termiczne zastosowanych rozwiązań.

Niekiedy już rozważenie kilku etapów działań termomodernizacyjnych może zmniejszyć energochłonność budynków i poprawić ochronę środowiska na obszarze osiedla. Zdaniem autorki dążenie do utrzymania zeroenergetycznego wzrostu kosztów eksploatacji budynków i mediów, tj. podejmowanie działań inwestycyjnych bez wzrostu zapotrzebowania na energię pierwotną w skali osiedlowej zabudowy wielorodzinnej jest możliwe przez sukcesywne wdrażanie następujących działań4:

- zlikwidowania mostków cieplnych w budynkach i sieci dostawców energii,

- zastosowanie odnawialnych źródeł energii z możliwością wielokierunkowego przesyłu,

- instalacja kolektorów słonecznych do ogrzania c.w. i produkcji prądu minimum w skali budynku i osiedla (zbiorowo),

- zastosowanie pomp ciepła $\mathrm{z}$ uwzględnieniem parametrów gruntu przy wydajności pompy,

- przebudowa węzła cieplnego i instalacji w ogrzewaniu zbiorowym, np. pieców działających w technice kondensacyjnej lub pieców niskotemperaturowych,

- regulacja instalacji w mieszkaniach i zastosowanie grzejników niskotemperaturowych dla instalacji c.o. z instalacją systemów regulacji w węzłach cieplnych, np. z użyciem czujnika temperatury zewnętrznej,

- izolacja wodnej sieci grzewczej,

- instalacja baterii zlewozmywakowych z termostatem,

- zastosowanie systemów zarządzania energią (ogrzewania zbiorowego na paliwa i prąd, pomiaru indywidualnego zużycia ciepła, optymalizacji obiegu),

- instalacja kondensacyjnych systemów rekuperacji lub kontrolowanej wentylacji mechanicznej,

- instalacja świetlówek kompaktowych klasy A lub oświetlenia LED,

- zakup sprzętu AGD klasy minimum A+,

- poprawa stanu i sprawności sieci dostarczających media do osiedla i budynków.

Zarządca, w porozumieniu z mieszkańcami powinien mieć możliwość, wyboru zakresu prac i współfinansownia etapowanych działań proenergetycznych z innych źródeł finansowania niż tylko fundusz remontowy. Wymaga to jednak zmiany obowiązujących przepisów ${ }^{5}$ i stworzenia organu kontroli realizacji takich inwestycji na każdym etapie działań przy kompleksowym ujęciu problemów.

This work was financially supported by Ministry of Science and Higher Education in Poland within the statutory research number S19/XX/201X.

4 Co potwierdza też wprowadzony mocą rozporządzenia katalog działań kwalifikowanych dających prawo do ubiegania się o białe certyfikaty i Polskie Towarzystwo Certyfikacji Energii, raport pt.: Analiza możliwości wprowadzenia w Polsce systemu bialych certyfikatów, s.10-12.

5 Ustawa o wpieraniu termomodernizacji i akty wykonawcze do ustawy [Dz. U. 43/2009 poz. 346 i Dz. U. 43/2009 poz. 347]. 


\section{BIBLIOGRAFIA}

Dzierżewicz Z., Starosolski Wł., 2010. Systemy budownictwa wielkoplytowego w Polsce w latach 1970-1985. Przegląd rozwiązań materiałowych i konstrukcyjnych. Oficyna a Wolters Kluwer business, s. 15-16.

Grudzińska M., Ostańska A., 2009. Rewitalizacja osiedli z budynkami wielkoblokowymi w aspekcie analizy energetycznej, PRZEGLĄD BUDOWLANY NR 6/2009, miesięcznik PZIiTB, ss.37-42.

Ostańska A., 2009. Badania społeczne jako podstawowy aspekt rewitalizacji osiedli, PRZEGLĄD BUDOWLANY NR 3/2009, miesięcznik PZIiTB, ss.48-53.

Ostańska A., 2009. Badania stanu technicznego jednym z podstawowych aspektów rewitalizacji osiedli z budynkami prefabrykowanymi, PRZEGLĄD BUDOWLANY NR 4/2009, miesięcznik PZIiTB, ss.38-46.

Ostańska A., 2010. Metodyka sporządzania programów rewitalizacji dla zespołów prefabrykowanej zabudowy mieszkaniowej na przykładzie osiedla im. Stanisława Moniuszki w Lublinie PRZEGLĄD BUDOWLANY 1/2010, miesięcznik PZiTB, ss. 38-43.

Ostańska A., 2011. Ocena poprawy jakości życia w budynkach prefabrykowanych na przykładzie opinii mieszkańców. Maszynopis 2011.

Ostańska A., 2009. Podstawy metodologii tworzenia programów rewitalizacji dużych osiedli mieszkaniowych wzniesionych w technologii uprzemystowionej na przykładzie osiedla im. St. Moniuszki w Lublinie, Politechnika Lubelska, Monografie Wydziału Inżynierii Budowlanej i Sanitarnej Vol.1, Wydawnictwa Uczelniane Lublin.

Ostańska A., 2009. Stan techniczny i analiza energetyczna jako podstawowe aspekty rewitalizacji osiedli z budynkami wielkopłytowymi, PRZEGLĄD BUDOWLANY NR 9/2009, miesięcznik PZIiTB, ss.40-47.

Rozporządzenie Ministra Infrastruktury z dnia 17 marca 2009 r. w sprawie szczegółowego zakresu i formy audytu energetycznego oraz części audytu remontowego, wzorów kart audytów, a także algorytmu oceny opłacalności przedsięwzięcia termomodernizacyjnego (Dz. U. 43/2009 poz. 346)

Rozporządzenie Ministra Infrastruktury z dnia 17 marca 2009 r. w sprawie szczegółowego sposobu weryfikacji energetycznego i części audytu remontowego oraz szczegółowych warunków, jakie powinny spełniać podmioty, którym Bank Gospodarstwa Krajowego może zlecać wykonanie weryfikacji audytów Dz. U. 43/2009 poz. 347).

Ustawa o wpieraniu termomodernizacji i remontów z dnia 21 listopada 2008r. (Dz. U. Nr 223, poz. 1459)

Ustawa prawo budowlane z dnia 7 lipca 1994r. Dz.U. z 2003r. nr 207, poz. 2016 z późniejszymi zmianami (art. 61. ustęp: 1 i 2).

\section{IMPROVING ENERGY PERFORMANCE OF A HOUSING ESTATE: ASSESSMENT OF ACTIONS TAKEN SO FAR IN PRECAST CONCRETE PANEL BLOCKS OF FLATS}

Summary. The paper investigates into results of thermal modernisation measures taken so far in typical housing blocks of W70 precast concrete panel system. The author proposes further energy performance improvements of the building and the estate.

Key words: thermal modernisation of buildings, energy performance, urban regeneration 